\title{
Accessibility and Inclusion in Higher Education: Implementing International Imperatives in National and Institutional Contexts
}

\author{
Palmira Jucevičien $\dot{e}^{1}$, Jurgita Vizgirdaité丶 ${ }^{2}$ Hanan Alexander ${ }^{3}$
}
1 Kaunas University of Technology, Faculty of Social Sciences, Humanities and Arts, 37 A. Mickevičiaus St., LT-44244 Kaunas, Lithuania, palmira.juceviciene@ktu.lt
2. Kaunas University of Technology, Faculty of Social Sciences, Humanities and Arts, 37 A. Mickevičiaus St., LT-44244 Kaunas, jurgita.vizgirdaite@ktu.lt
3 University of Haifa, Faculty of Education, 199 Aba Khoushy Ave.Mount Carmel, Israel IL-3498838, Haifa, hanana@edu.haifa.ac.il

\begin{abstract}
This paper reports on a capacity-building project in higher education known as DARE (Developing programs for Access of disadvantaged groups of people and Regions to higher Education), as viewed through the lenses of Hanan Alexander's pedagogy of difference, Uri Bronfenbrenner'sbioecological theory of human development, and Chris Argyris's concept of action science. The project is funded by the European Commission's Education, Audiovisual and Culture Executive Agency. Following a literature review, the report analyzes data drawn from documents, observations, and focus groups to explore how and why policies addressing accessibility to higher education for disadvantaged groups are implemented in different international contexts. Influenced by international initiatives, DARE has provided material, conceptual, professional, and collegial resources to have an overall positive effect on advancing access to and inclusion in higher education for minorities, students with disabilities, and women. Our analysis of the case found, following Alexander, that there may be common norms, challenges, and reasons why it is desirable to affirm access to and inclusion in HE, but following Bronfenbrenner and Argyris, there are also national and institutional differences that call for distinctive policy initiatives to achieve these aims according to country, region, and individual universities and colleges.
\end{abstract}

Keywords: accessibility, higher education, disadvantaged groups, inclusion, people with disabilities, women, ethnic minorities. 


\section{Introduction}

Access to higher education (HE) is one of the significant goals embraced by the EU (European Commission et al., 2015), OECD (2014) and UNESCO (2015a, 2015b). Although these international bodies share a common understanding of what accessibility to $\mathrm{HE}$ means and how it ought to be achieved, comparative research (Hendriks, 2007; Morley, 1997) suggests that various countries and institutions employ quite different approaches to the issue. Indeed, despite the common policy guidelines formulated by the EU, OECD, and UNESCO, many countries still implement their own independent policies based on competing local understandings of the very concept of accessibility (Riddell et al., 2005). Countries that aim to increase accessibility to HE as understood by these international bodies often develop concrete goals, policies, and practices to implement on the institutional level that conform to the growing international understanding of the term(European Commission et al., 2015).

Relevant scholarship mainly concentrates on what accessibility means (Grigal et al., 2011), on policies and their results (Usher, Cervenan, 2005; Bordoloi, 2012), or on support services that address problems of accessibility (Sachs, Schreuer, 2011; DeMillo, Young, 2015; van Rooij, Zirkle, 2016). However, there is a lack of research concerning the impact of national or institutional contexts on the implementation of various means to increase accessibility to and inclusion in HE. To begin to address this deficit, our study focused on the contexts that condition different means used by HE institutions to increase accessibility to HE brought about within a capacity-building project in Higher Education known as DARE (Developing programs for Access of disadvantaged groups of people and Regions to higher Education). Funded by the European Commission's Education, Audiovisual and Culture Executive Agency, the project promotes initiatives addressing access to and inclusion in HE with eight universities and collegesin two countries: Israel and Georgia.

Using this project as a basis for a case study, our aim was to examine how and why policies are implemented within the framework of the project that address accessibility to and inclusion in higher education for disadvantaged groups, based on international norms within the eight participating universities and colleges in these two nations. Specifically, given accepted definitions of accessibility and inclusion in HE within relevant international bodies, we sought to identify and understand factors on national and institutional levels that might facilitate the recruitment and retention of people to HE from three often marginalized groups: (1) those who are cognitively, socially, or physically disabled; (2) women; and (3) cultural, religious, racial, ethnic, or national minorities.

This paper is divided into six parts. After this introduction, which is Part One, Part Two presents a perspective on accessibility agreed upon by relevant international bodies followed by the theoretical background for our analysis: Hanan Alexander's pedagogy of difference (Alexander, 2015), Uri Bronfenbrenner's ecological and bioecological theory of human development (Bronfenbrenner, 1979, 2005), and Chris Argyris's concept of 
action science (Argyris et al., 1985; Argyris, 1995). The third part describes our research methodology and research question. In the fourth and fifth parts, data from the DARE project is presented and discussed in light of our conceptual framework. Part Six offers some final considerations in conclusion.

\section{Theoretical Background}

\subsection{Accessibility to HE from an International Perspective}

We use the term "accessibility" here according to international organizations' definitions that have been officially adopted in many countries. UNESCO's Convention against Discrimination in Education (1960) is exceptionally informative in this regard (Singh, 2008). It is the first international document to specify education as a human right by seeking to ensure "full and equal opportunities for education for all" (Article 1a),binding all countries that signed the Convention to formulate and implement national policies relevant to their particular contexts (Article 4). This objective is facilitated across Europe through the legal and academic standardization of HE by the Bologna Process (Riddell et al., 2005) for disabled students, women, and those from minority backgrounds.

International bodies have devoted special attention to accessibility for people with cognitive, social, and physical disabilities. For instance, the UN Convention on the Rights of Persons with Disabilities (2006) was signed by 92 countries. Consideration is also given to women as a group whose access to HE as compared to men's access was for a long time denied or limited. Today, there are more women studying in HE institutions than men (Usher, Cervenan, 2005). However, the comparative number of females in colleges and universities decreases as they advance to graduate studies and to careers in academic teaching, research, and administration, perhaps in part due to inadequate polices concerning parental leave and child care. These problems may be especially acute among women from underrepresented ethnic backgrounds, whose advancement in HE institutions or through HE to careers inother fields has been historically restricted (Bordoloi, 2012; Oplatka, Lapitod, 2012).

More recently, the emphasis in international discussions concerning access to $\mathrm{HE}$ has turned to addressing the recruitment and retention of students from disadvantaged groups based on socioeconomic, ethnic, national, racial, or religious origins, especially by making HE affordable (Usher, Cervenan, 2005). For instance, the European Commission's Eurodyce Brief, Modernisation of Higher Education in Europe (2015), defined access as "widening participation in higher education by ensuring equal opportunities to all sections of society, irrespective of socio-economic background and other factors which may lead to educational disadvantage" (ibid, 4), where student retentionis defined as "the extent to which students remain within a higher education institution and progress to complete their study program within a given time frame" (ibid, 13). That said, it is 
admitted that "progress in implementing policy to widen access varies greatly between countries" (ibid, 5; also Flannery, Cullinan, 2014).

Turning from recruitment to retention requires that we consider how disadvantaged groups are integrated into and supported within HE institutions, in addition to quantitative indicators as to who is admitted. This requires a discussion of inclusion in addition to access. While "accessibility is passive $\langle\ldots\rangle$ inclusion is active-inviting you into the human network beyond the newly barrier-free doorway" (Rains, 2012, p. 10). This requires the existence of an inclusive culture in HE institutions that actively seeks to widen participation, characterized not only by the declared values of an institution but also by an infrastructure for empowerment that puts these values into practice and by the subtle attitudes of teachers and students to embrace those who may be different from themselves.

\subsection{Alexander's Pedagogy of Difference}

Why are accessibility and inclusion important to HE? According to the international documents mentioned, education is a universal right that societies are obliged to provide for all of their citizens, especially those who have previously been denied access. Hanan Alexander's (2015) educational theory known as "pedagogy of difference," which provides the philosophical background for DARE, offers three additional reasons why accessibility and inclusion are important to HE: (1) human experience is fundamentally diverse, (2) being educated requires a critical attitude that entails the capacity to view things from a variety of perspectives, and (3) academic excellence involves student success in addition to good teaching and quality research.

Pedagogy of difference is based on the simple idea that to know oneself one must engage others who are different, but to engage others one must know oneself. This idea is relevant to education in open liberal democracies because it takes seriously the fact of pluralism. People experience their humanity by way of different, sometimes overlapping and in other instances incommensurable, cultures; classes; religions; ethnicities; nationalities; languages; races; genders; sexual orientations; cognitive, social, and physical abilities; and more. An education to enable diverse populations to participate actively in such a democracy is a social necessity, not only an individual right, required to enable citizens to forge a modus vivendi to live together peacefully in one common civil society despite, or perhaps even because of, their differences. People who hail from distinct backgrounds or who have experienced challenges or disabilities of one kind or another have unique perspectives that can enrich the academic discourse of higher learning and enhance the possibility of dialogue across a rich diversity of cultures, traditions, and perspectives (Alexander, 2015, p. 89).

Additionally, this plurality of voices stands to make an important contribution to the sort of critical attitude required for quality academic research and teaching that are the hallmarks of HE. It may have once been agreed that the sort of critical thinking essential 
to an education worthy of college and university studies entaileda capacity for hypothetical-deductive reasoning characteristic of the empirical sciences. However, this perspective has been subjected to hard criticism from a variety of vantage points, especially those of critical social theory; which holds that a genuinely critical viewpoint entails appropriate attention to the sometimes hidden influence of an inequitable distribution of power and position in social relations. In an age in which we no longer agree about criteria to distinguish education from ideological indoctrination or academic research from mere opinion or propaganda, a critical viewpoint can gain a foothold by juxtaposing different perspectives, both as insiders might experience a particular theory, culture, or tradition, and how it might be assessed according to one or a number of alternative viewpoints.

Finally, there is a strong tendency to evaluate HE institutions in terms of meritorious teaching and research on the part of faculty members alone, without reference to students. However, excellence in HE also requires the third leg of this three-legged stool-student success. In addition to demonstrated academic capabilities, students come to colleges and universities with a variety of learning needs. Many of these are tied to aspects of their backgrounds that often remain unacknowledged in HE classrooms, relating to culture; language; gender; cognitive, social, and physical challenges; and more. In addition to recognizing the important contributions of these diverse backgrounds to coexistence and criticism, pedagogy of difference also requires attention to the particular lives that students bring to higher learning in all of their complexities in order to assist them in addressing the challenges that these backgrounds may pose to academic success.

\subsection{Bronfenbrenner on the Contextual Factors of Human Development}

What should be the substance of policies and practices concerning access to and inclusion in HE? This brings us to the importance of national and institutional contexts in properly addressing the developmental needs of students from disadvantaged and marginalized groups. Bronfenbrenner's $(1979,2005)$ ecological and bioecological theories of human development are especially useful in this regard. The former addresses the significance of national context at what he calls the macro level, and the latter considers how the inclusion processes might work at the institutional,or what he calls the proximal, level.

According to Bronfenbrenner's ecological theory (Bronfenbrenner, 1979), humans grow and develop through a dynamic process of interaction with their surroundings, which he calls an ecological system. At the most basic micro level, these are comprised of face-to-face interactions with family and friends at home and at school. As one moves beyond these immediate relationships, development expands to include more complex mesosystems such as extended families and neighborhoods, exosystems such as media and other means of mass communication, and eventually macrosystems such as culture, law, economics, and religion.

This ecological theory became the grounds for a bioecological theory of human development (Bronfenbrenner, 2005) that emphasizes three factors in interactions: the 
person, the duration of an interaction, and the space in which it transpires. This theory explores how personal characteristics in conjunction with different contextual elements influencethe "proximal processes" that Bronfenbrenner called the "engines of development" (Rosa, Tudge, 2013).

\subsection{From Policy into Practice: Argyris on Espoused Theories and Theory-in-Use}

How should these policies and practices be implemented such that they become fully integrated into the values, infrastructure, and culture of HE institutions? This requires reflection-a special form of learning that brings into focus the differences between knowledge related to the planning of an action and knowledge related to the implementation of an action.

According to action science (Argyris et al., 1985; Argyris, 1995), when formulating plans to take an action, one constructs a conception of that action called an "espoused theory", grounded on explicit knowledge. However, in the process of implementing those plans, one may encounter unforeseen circumstances that challenge those preconceptions. In response, one often changes the espoused theory subconsciously to a "theory-in-use" that is implicit in one's actions. This results in "tacit" knowledge, which impacts a person's actions in latent ways that are not recognized. Some part of one's tacit knowledge may be transformed into explicit knowledge by means of reflection (Staniškiene, 2005).

\section{Research Methodology}

\subsection{Research Methods and Questions}

The methodology of our research was a qualitative case study. According to this method, a robust example is documented based on participant observations, reports from discussion groups, and material culture such as project proposals, institutional reports, and other documents. The data is then interpreted in light of a theoretical framework grounded in the scholarly literature to address relevant research questions. The case study method is chosen when a logic of illustration is more useful to highlighting important aspects of individual or organizational behavior than is analyzing statistical relationships between variables, particularly when research questions involve the purposes or intentions of human activity rather than the ways in which behaviors are caused or correlated (Yin, 2013). In this case, we sought to understand whether and in what ways national and institutional contexts could influence the formulation and implementation of policies based on international norms aimed at recruiting and retaining three target populations presumed to have been previously marginalized from HE-those with cognitive, social, or physical disabilities; cultural, religious, racial, ethnic, or national minorities; and women-working with international definitions learned through participation in a capacity-building project of the European Commission's Education, Audiovisual and Culture Executive Agency. We hypothesized that there were likely to be commonalities among 
the reasons for addressing these challenges based on Alexander's pedagogy of difference, but that there might be national differences in specific challenges faced and the substance of policies adopted that could be explained in terms of Bronfenbrenner's environmental theories of human development and institutional differences that could be understood in terms of Argyris's distinction between espoused theories and theories-in-use.

\subsection{The Case}

The EU Erasmus+ Key Action 2 DARE project that served as the case for examination in this study aims at promoting inclusive education in Georgia and Israel by widening access to higher education for potential and existing students from three vulnerable groups: women, ethnic minorities, and those with disabilities. It also addresses the needs of potential students who live in peripheral areas according to the Bologna Process and to United Nations criteria. It aims to advance the rights of individuals with specific needs to access education, to participate in everyday life in their respective societies, and to overcome discrimination against them by raising awareness and advocating acceptance. The differentiation of these groups is relevant for the higher-education institutions of Israel and Georgia, because they reflect the national priorities established by the relevant $\mathrm{HE}$ authorities in each country. These were the countries chosen by the project to benefit from the advice and experience of four HE institutions and one NGO in five European countries: the UK, Spain, Lithuania, Romania, and the Czech Republic. Coordinated by one of the Israeli HE institutions, DARE engaged the universities and colleges in the regions of each country in which the percentage of one or another of the target disadvantaged populations is higher than the average for the entire country. Although the two beneficiary countries are distinct economically, politically, culturally, and educationally, they share the stated aim of the project, which includes modernizing the governance, management, and functioning of $\mathrm{HE}$ institutions as well as transferring best practices relating to access, wider participation, equal treatment, and improved retention rates.

The eight participating HE institutions from Israel and Georgia are designated as beneficiaries of the project. This means that they are expected to benefit from the advice offered by the five participating European institutions and from the collaboration among all of the participants in the consortium. Evidence of this benefit should be seen in new policies and practices concerning access to and inclusion in $\mathrm{HE}$ implemented as a consequence of participation in the project. Of the Israeli institutions, one is a research university. It is authorized by Israel's Council of Higher Education (CHE) to grant undergraduate, master's, and $\mathrm{PhD}$ degrees with both professional and research orientations. Two of the Israeli participants are academic colleges authorized to grant BAand MA degrees in arts and sciences with the primary focus of professional training. The final Israeli participant is an academic college of education authorized to grant bachelor's and master's degrees in education and teaching diplomas. Of the four Georgian institutions, two are research universities granting all three levels of academic degrees on both professional 
and research tracks. One is housed permanently in the capital. The second is exiled from its home city due to Russian occupation and so is housed temporarily in the capital. The other two are regional universities, the equivalent to Israeli colleges. In both countries, the participating HE institutions are distributed across diverse geographical regions.

The three-year project intends to improve institutional capacities by reinforcing support services at Georgia and Israel partner universities, to train faculty members and professional and administrative staff on the use of the established or reinforced services for vulnerable target groups, and to reach out to the three targeted groups by offering a support system via information and communication technologies (ICT) with tutorials and selected course programs. It further seeks to raise awareness in society in general and in the national ministries of education of the participating countries in particular concerning the needs of these marginal populations, with a view to disseminating good practices to other HE institutions.

\subsection{Sources of Data}

We benefitted from having access to data for this case study because we were participants in the DARE project. The various national and institutional policies and practices that were formulated and initiated by institutions in Israel and Georgia that benefit from DARE are analyzed below based on four sources of qualitative data: (1) participant observations conducted during the first consortium meeting at the University of Murcia in February 2016; (2) notes of discussion groups at that consortium meeting on the planning of DARE activities at participating institutions; (3) documents, including the DARE project proposal, the midterm implementation report, and the Assessment Tools for Student Support Services; and (4) information taken from the DARE website (https:// dare.erasmus-plus.org.il/course/view.php?id=52).

\subsection{Research Ethics}

Because this case study emphasized institutional research, in order to avoid negatively impacting aninstitution's reputation or adversely affecting participating human subjects, all research ethics practices were followed according to Helsinki guidelines. This includes, but is not limited to, the requirement of anonymity for all participating institutions and individuals.

\section{Findings}

Our findings are presented as follows:(1) The legal requirements relating to the challenges of access to and inclusion in HE;(2) The challenges faced by participating institutions in each country concerning access to and inclusion of the target groups; and(3) The changes in policy and practice implemented to address those challenges. 


\subsection{The Legal Requirements of Access to HE}

EU-associated countries, as well as countries seeking membership in the EU, are required to accept initiatives of the EU aimed at resolving problems of disadvantaged groups by increasing access to $\mathrm{HE}$ and emphasizing inclusive education. However, even when laws have been passed in a specific country concerning access to and inclusion in $\mathrm{HE}$, they may not be easy to implement in practice. This may be the case in EU partner countries such as Israel and Georgia, in which initiatives at the legal level are implemented unevenly in the various participating universities and colleges.

In general, due to policies passed by Israel's Council of Higher Education, Israeli HE institutions have more experience than their Georgian counterparts do with access and inclusion. All of the Israeli participating institutions demonstrated significant experience in educating people with cognitive, social, and physical disabilities. Two institutions emphasized their experience in addressing special issues pertaining to access and advancement for women in $\mathrm{HE}$ and two underlined their experience in addressing issues relating to ethnic, linguistic, and national minorities. That said, some challenges remain to be addressed for all three target groups. These institutions tended to focus their DARE projects on people with disabilities, since the CHE Committee on Budget and Planning funds extensive national programs to integrate Arab and ultra-Orthodox minorities into HE (Sachs, Schreuer, 2011). The Israeli DARE partners emphasized the following as legal requirements for access to and inclusion in HE: Equal Rights for Persons with Disabilities Law (1998), admissions standards acceptable to the relevant academic authorities, and requirements for examination accommodations for students with disabilities.

Georgian HE faces many challenges, especially given the country's socioeconomic situation. To address these challenges, HE institutions must address a range of legal requirements. In this connection, project partners may rely on the following relevant documents: Georgian higher education law (2004); Georgian general education law (2005); Law on integration; Law on the disabled people; Educational standards for students with special needs; Law on Vocational Education of Georgia (2007); Vocational education and training development strategy for 2013-2020 (2013); and National Curriculum (2011). In addition, the international initiatives, which Georgia has joined, partner institutions also emphasized the Convention on the rights of persons with disabilities.

\subsection{Challenges of Access to and Inclusion in HE}

\subsubsection{Israeli Challenges}

In the discussions and documents that we examined, Israeli participants mentioned the following challenges regarding access to and inclusion in HE:

Challenges for people with disabilities

- Admissions standards resulting in students not being able to meet the basic standards to be accepted to study at a college or university or being afraid to try, having low self-esteem, experiencing social isolation, facing stigma in regard to 
their ability to learn, and some admissions committee members at colleges or universities stigmatizing the se students' capacities for academic studies

- Having a higher dropout rate because of a lack of basic learning skills and learning strategies, bad learning experiences, a lack of basic knowledge of English, or a lack of awareness of the services offered by the University for the target group

- Low self-esteem developed during their studies, possibly impacting their willingness or readiness to apply for jobs after graduation

- Lack of social awareness regarding the accessibility of HE within their society at all levels (policy makers, stakeholders, lecturers, administrative staff, students, etc.)

- Lack of a center to provide coordinated services with in one unit to the target group

- A shortage of professional staff for training and supporting students with disabilities

- Lack of equipment

Challenges for women

- Mothers of small children having difficulty finding a professional place to leave their babies/children while they are returning to study after maternity leave, sometimes leading them to dropout of their studies

- Financial barriers

Challenges for women from minority groups

- Social alienation

- Lack of basic requirements to enter an HE institution (not having a Matriculation Certificate or not having taken the Psychometric Exam)

- Lack of awareness or understanding of the importance of HE or lack of knowledge/ information about university or academic studies

- Language barriers

- Limited orientation to digital/technological literacy and use

- Learning disabilities

- Physical distance between home and college

Challenges for minorities

- Lack of basic requirements to enter an HE institution (not having a Matriculation Certificate or not having taken the Psychometric Exam)

- Language barriers

- Lack of awareness or understanding of the importance of HE or lack of knowledge/ information about university or academic studies

- Lack of motivation to obtain higher education

- Lack of social awareness, particularly for relatively closed minority communities

- Coming from a poor socioeconomic background - educational costs and housing and living expenses being very high and preferring to go out into the labor market

- Traditional reasons as to social norms-e.g., marrying at a young age, lacking family and societal encouragement to continue their studies at a university, etc. 


\subsubsection{Georgian Challenges}

In the discussions and documents that we reviewed, Georgian project partners emphasized the following problems and barriers to fostering accessibility and inclusion in HE:

Challenges for people with disabilities

- Integration difficulties - students with special needs finding it difficult to socialize with other students

- Language barriers and insufficient use of language services

- Lack of knowledge and skills regarding modern educational strategies and technologies

- Limited access to modern technologies

- Financial barriers - tuition and fees

Challenges for women

- Freedom of choice and having a family

- In some regions, families still making decisions for girls as to whether or not to study, where to study, or what to study

- Because of having children and families, female students having to leave college before finishing their studies

Challenges for minorities

- The problem of crossing borders

- The attitude of the majority toward the minority

- Lack of information regarding entering HE

- Lack of knowledge necessary to study HE or not having a Matriculation Certificate

- Lack of resources to buy quality textbooks

- Lack of qualified teachers who know how to work with new textbooks

- Different academic standards - the false perception that teachers may have that they need to lower standards during the teaching and learning process

- Lack of financial resources to be able to study

\subsection{Institutional Changes Implemented to Address these Challenges}

The institutional changes implemented to address these challenges revealed in the documents and discussions that we reviewed are summarized in Table 1.The vertical access addresses each country according to institution. The horizontal access summarizes interventions according to target groups, such as psychological developmental (PD) tools impacting self-esteem of the individuals from target groups or awareness of the administrative or academic staff. We refer to the Israeli institutions as A, B, C, and D and the Georgian institutions as E, F, G, and H. 
Table 1

Institutional changes implemented to increase access and inclusion during DARE

\begin{tabular}{|c|c|c|c|c|c|c|c|c|}
\hline \multirow[t]{2}{*}{ Country } & \multirow[b]{2}{*}{$\begin{array}{c}\text { HE Insti- } \\
\text { tution } \\
\text { DARE } \\
\text { Project } \\
\text { Partner }\end{array}$} & \multicolumn{3}{|c|}{ For People with Disabilities } & \multicolumn{2}{|c|}{ For Women } & \multicolumn{2}{|c|}{ For Minorities } \\
\hline & & $\begin{array}{l}\text { Cogni- } \\
\text { tive and } \\
\text { Social } \\
\text { Disabili- } \\
\text { ties }\end{array}$ & $\begin{array}{l}\text { Physical } \\
\text { Disabili- } \\
\text { ties }\end{array}$ & $\mathrm{PD}$ & All & $\mathrm{PD}$ & All & $\mathrm{PD}$ \\
\hline \multirow{4}{*}{ IL } & A & + & + & + & + & + & + & + \\
\hline & B & & & & + & + & & \\
\hline & $\mathrm{C}$ & + & + & + & & & & \\
\hline & $\mathrm{D}$ & + & + & + & & & & \\
\hline \multirow{4}{*}{ GE } & $\mathrm{E}$ & & + & + & & & + & + \\
\hline & $\mathrm{F}$ & + & + & + & & & + & + \\
\hline & G & + & & & & & + & \\
\hline & $\mathrm{H}$ & & + & & + & & + & \\
\hline
\end{tabular}

From the outset, the DARE proposal presupposed that different institutions would implement a variety of policies and practices with differing emphases on the three target groups based on their own contextual needs. This is seen in Table 1, which shows that DARE partners chose to emphasize different target groups and alternative initiatives to address their respective challenges concerning accessibility to and inclusion in HE. Most of the attention was devoted by higher education institutions to people with cognitive, emotional, and physical disabilities. Seven of the eight institutions had initiatives in this category. However, of these seven, only four emphasized all three types of disabilities. Georgian HE institutions tended to focus attention more specifically on fewer types of disabilities. Five of the eight institutions created policies addressing the needs of minorities, one from Israel and four from Georgia. Three of the eight institutions instituted policies addressing the needs of women, two from Israel and one from Georgia. Two institutions included all three target groups; only one targeted all three subcategories within all three target groups. Three out of eight emphasized two target groups. Three institutions implemented innovations for only one of the three target groups. Five institutions started developing programs to enhance competencies for administrative or academic staff to increase access and inclusion, two institutions strove to increase accessibility for women, and three institutions strove to increase accessibility for minorities. 


\section{Discussion: The Role of Context in Access to and Inclusion in HE}

Are national and institutional contexts a significant factor when considering access to and inclusion in HE for marginal groups, and if so, in what ways? Our interpretation of the data confirms the hypothesis of this paper: Following Alexander, there may be common norms, challenges, and reasons why it is desirable to affirm access to and inclusion in HE. However, following Bronfenbrenner and Argyris, there are national and institutional differences that call for distinctive policy initiatives to achieve these aims according to country, region, and individual universities and colleges. We will first consider the commonalities and then turn to the differences.

\section{Commonalities}

Each of these societies has followed emerging international norms by passing legislation to eliminate discrimination against these traditionally underrepresented groups in $\mathrm{HE}$ by fostering policies to enhance access and inclusion. This reflects a gradual change in attitudes, prejudices, and stereotypes concerning those who are different than that which is perceived as the social mainstream. Yet, the lofty ends of access and integration cannot be achieved via legislation alone. There are common challenges faced in both countries. These include: lack of awareness of the need for access and inclusion, particularly among administrative and academic staff; a false belief that students from the target populations cannot meet academic standards for admission or will lower the academic level of studies if admitted; lack of knowledge within some of the target populations, especially of languages necessary for academic studies; low self-esteem among some target groups that generates psychological barriers to integration among potential students; lack of teachers competent to teach some of the target groups, particularly people with disabilities and minorities; lack of infrastructure for people with disabilities; and lack of specialized equipment for teaching and learning. Although these common challenges may have different qualitative and quantitative parameters in each country, addressing them will require the same deep philosophical commitment, starting with early education and continuing through all levels of schooling, including HE. In its embrace of Alexander's pedagogy of difference in both countries, DARE offers a model across contexts of why engaging those who are different from oneself is a necessity for academic quality in education (Alexander, 2015).

The DARE findings also reveal that less attention in the participating institutions of both countries is currently paid to access for and inclusion of women than to the needs of minorities or people with disabilities. This is perhaps because the number of women studying in universities and colleges in both settings is higher than that of men. In universities and colleges in Israel, 58\% of students are female, and in Georgia, 54\% are women. However, it does not follow that the problems of women's participation in HE have been totally resolved. Challenges for mothers of young children and for advancement 
of women within academic careers are often noted by participants from both counties. Both countries have demonstrated sensitivity toward women's participation in HE, especially among those from traditional lifestyles that may limit the equality of women in social life (Oplatka, Lapidot, 2012).

\section{Differences}

According to Bronfenbrenner's (1979) perspective, various environmental factors may play a part in the differences between each national context, both in terms of challenges that may be unique to each context as well as the ways the challenges are addressed in policy initiatives. One such environmental factor could be the difference in economic status in each society. Lower levels of economic resources will usually restrict the possibilities for policy innovation, especially those that may benefit underrepresented populations with limited power. This may explain why Israel has allocated greater resources to date than has Georgia to address issues regarding the needs of marginalized populations such as minorities or those with disabilities. Israel is now celebrating its 70th year of independence, during which time it has created a robust economy. On the other hand, Georgia only declared its independence from the Soviet Union in 1991 and is still in the process of cultivating economic development.

Of course, economics is but one of the environmental factors that may impact access to and inclusion in HE. Bioecological theory (Bronfenbrenner, 2005) reminds us that the duration of the impact of environment is also important. Low self-esteem among people with disabilities is influenced by this factor, for example, since this issue has only been addressed in the professional literature over the past several decades. This may have left self-esteem issues unaddressed over many years. Combined with economic considerations, this can help to explain why, in recent years, fewer resources have been devoted in Georgia than in Israel to enabling students with cognitive, social, and physical disabilities to study in $\mathrm{HE}$ institutions. It also reinforces the importance of translating international imperatives into national legislation and regulation, to reduce stigmatization of and increase academic opportunities for citizens with these challenges.

Argyris's distinction between espoused theories and theories-in-use can also be useful in understanding institutional differences in enumerating and addressing the challenges of access to and inclusion in HE. According to this theory, performance is impacted partially unconsciously by when an espoused theory is transformed into a theory-in-use. Staniškiene (2005) has applied this analysis to institutional decision-making regarding translation of international norms and national regulations into institutional policy and practice. In this view, it is not surprising that the ideas introduced by international conventions and declarations and national legislation are significantly altered when applied to specific institutional circumstances.

For example, Sachs and Schreuer (2011) compared the quality of the preparation of students with disabilities for academic studies in Israel to that of traditional students, 
along with the conditions fostering their academic success once admitted. They showed that flexibility in admissions requirements for the target groups had little relation to academic achievement, while use of information and communication technologies (ICT), on the other hand, positively influenced student achievement and satisfaction. Although different types of disabilities remain a significant factor influencing student achievement and satisfaction, they concluded that "students with and without disabilities did not differ in their overall experiences of academic participation....Achievements of students with disabilities proved only slightly below those of students without disabilities"(Sachs, Schreuer, 2011).

Based in part on findings such as these, Israel's Council for Higher Education has issued policy directives for HE institutions to consider appropriate accommodations in admissions and examination of students with disabilities, and the National Insurance Institute has funded centers for services to address the needs of these students. Yet, due to considerable resistance from academic circles that consider these accommodations to constitute a lowering of academic standards, not all of Israel's HE institutions have instituted the full measure of these accommodations or availed themsleves of the funding provided by the National Insurance Institute. Similarly, despite national regulations, until very recently we have not seen similar initiatives in Georgian HE institutions. Following Argyris' saction theory, HE institutions in both countries should seek to adjustthe international norms and national regulationsas espoused theory intolocal institutional practices as theories-in-use.Such application will provide thesetarget groups with the necessary accommodations and modern learning tools to enhance their academic success(Lee, 2017).

\section{Conclusion}

International conventions, declarations, and norms can serve as a sufficient basis to motivate national regulation of access to and inclusion in HE. According to these international standards, access to HE for disadvantaged groups should involve social inclusion, not only affordability, reasonable accommodations, and academic success. However, national regulations may vary from one country to another shaped by a variety of mitigating factors such as political stability, socioeconomic conditions, public opinion, and the ability to enforce relevant legislation. On the institutional level, access and inclusion depend on a willingness within colleges and universities to translate international norms and national legislation into local policies and practices, depending on the institution's degree of autonomy from centralized authorities.

A cogent educational philosophy such as Alexander's pedagogy of difference may be useful to persuade institutional authorities of the academic and social advantages of implementing these policies. Following Bronfenbrenner's ecological and bioecological 
theories of human development, it is also important that the substance of these policies and practices take into account social, cultural, and psychological needs and sensitivities of the target populations. This requires that academic and administrative staff be appropriately trained to address these needs and sensitivities in teaching, learning, and institutional management, such as by means of the appropriate use of information and communication technologies. It further requires that these policies and practices be translated from what Argyris called espoused theories into local theories-in-use that are appropriately adapted to the circumstances of particular HE institutions.

\section{References}

Alexander, H. (2015). Reimagining liberal education: Affiliation and inquiry in democratic schooling. London, England: Bloomsbury Publishing.

Argyris, C. (1995). Action science and organizationallearning. Journal of ManagerialPsychology, 10(6), $20-26$.

Argyris, C., Putnam, R., \& Smith, D. M. (1985). Action Science, 13. San Francisco, CA: Jossey-Bass. Bordoloi, R. (2012). Accessibility and equity: A challenge for higher education in India. Journal of Economics and Sustainable Development, 3(4), 67-78.

Bronfenbrenner, U. (1979). The ecology of human development. Cambridge, MA: Harvard University Press.

Bronfenbrenner, U. (Ed.) (2005). Making Human Beings Human: Bioecological Perspectives on Human Development. Thousand Oaks, CA: Sage.

DeMillo, R. A., \& Young, A. J. (2015). Revolution in Higher Education: How a Small Band of Innovators Will Make College Accessible and Affordable. Cambridge, MA: MIT Press.

European Commission/EACEA/Eurydice. (2015). Modernisation of higher education in Europe: Access, retention and employability 2014. Eurydice Brief. Retrieved from https://publications. europa.eu/en/publication-detail/-/publication/b1e5b242-7bac-11e5-9fae-01aa75ed71a1/ language-en.

Flannery, D., \& Cullinan, J. (2014). Where they go, what they do and why it matters: The importance of geographic accessibility and social class for decisions relating to higher education institution type, degree level and field of study. Applied Economics, 46(24), 2952-2965.

Grigal, M., Hart, D., \& Weir, C. (2011). Framing the future: A standards-based conceptual framework for research and practice in inclusive higher education. Think College Insight Brief, 10, 1-3.

Hendriks, A. (2007). UN Convention on the Rights of Persons with Disabilities. European Journal of Health Law, 14, 273-280.

Lee, K. (2017). Rethinking the accessibility of online higher education: A historical review. The Internet and Higher Education, 33, 15-23. 
Morley, L. (1997). Change and equity in higher education. British Journal of Sociology of Education, $18(2), 229-240$.

OECD. (2014). Fostering equity in higher education: Fostering inclusion of disadvantaged students. Retrieved from http://www.oecd.org/education/imhe/Fostering-inclusion-of-disadvantagedstudents.pdf.

Oplatka, I., \& Lapidot, O. (2012). Muslim women in graduate studies: Some insights into the accessibility of higher education for minority women students. Studies in Higher Education, 37(3), 327-344.

Rains, S. (2012). Accessibility is not inclusion. In IIBM \& 4W (Organizers),Enabling access for persons with disabilities to higher education and workplace: Role of ICT and assistive technologies (pp. 10-11). Retrieved from file://C:/Users/Owner/Downloads/Journal-\%20Enabling\%20 Access\%20for\%20Persons\%20with\%20Disabilities\%20to\%20Hi\%20(6).pdf,

Riddell, S., Tinklin, T., \& Wilson, A. (2005). Disabled students in higher education: Perspectives on widening access and changing policy. Abingdon, England: Routledge.

Sachs, D., \& Schreuer, N. (2011). Inclusion of students with disabilities in higher education: Performance and participation in student's experiences. Disability Studies Quarterly, 31(2). doi: http://dx.doi.org/10.18061/dsq.v31i2.1593

Singh, K. (2008). UNESCO's Convention against Discrimination in Education (1960): Key pillar of the education for all. International Journal for Education Law and Policy, 4, 69-83.

Staniškiene, E. (2005). Švietimo politikos igyvendinimo problemu tyrimo metodologija (Lietuvos švietimo reformos aspektas) (Unpublished doctoral dissertation). Kaunas University of Technology, Kaunas, Lithuania.

UNESCO. (2015a). Incheon Declaration and Framework for Action for the implementation of Sustainable Development Goal 4: Ensure inclusive and equitable quality education and promote lifelong learning opportunities for all. Retrieved from http://unesdoc.unesco.org/ images/0024/002456/245656E.pdf

UNESCO. (2015b). The right to education for persons with disabilities: Overview of the measures supporting the right to education for persons with disabilities reported by member states. Retrieved from http://unesdoc.unesco.org/images/0023/002325/232592e.pdf

Usher, A., \& Cervenan, A. (2005). Global higher education rankings: Affordability and accessibility in comparative perspective, 2005. Stafford, VA: Educational Policy Institute. Retrieved from http://www.educationalpolicy.org/pdf/Global2005.pdf.

van Rooij, S. W., \& Zirkle, K. (2016). Balancing pedagogy, student readiness and accessibility: A case study in collaborative online course development. The Internet and Higher Education, 28, 1-7.

Yin, R. K. (2013). Validity and generalization in future case study evaluations. Evaluation, 19(3), 321-332. 


\title{
Kodèl ir kaip aukštojo mokslo prieinamumas socialiai jautrioms grupèms yra kontekstualizuotas?
}

\author{
Palmira Jucevičienè ${ }^{1}$, Jurgita Vizgirdaite் ${ }^{2}$, Hanan Alexander ${ }^{3}$
}

1 Kauno technologijos universitetas, Socialinių, humanitarinių mokslų ir menų fakultetas, A. Mickevičiaus g. 37, 44244 Kaunas, palmira.juceviciene@ktu.lt

2 Kauno technologijos universitetas, Socialinių, Humanitarinių mokslų ir menų fakultetas, A. Mickevičiaus g. 37, 44244 Kaunas, jurgita.vizgirdaite@ktu.lt

3 University of Haifa, Faculty of Education, 199 Aba Khoushy, Ave. Mount Carmel, IL-3498838 Haifa, Israel hanana@edu.haifa.ac.il

\section{Santrauka}

Šio darbo tikslas - nustatyti, kaip ir kodèl aukštojo mokslo prieinamumas socialiai jautrioms grupèms yra kontekstualizuotas.

Tyrimo uždaviniai:

1. Išryškinti esmines teorines ir metodologines pozicijas, leidžiančias ịsigilinti i aukštojo mokslo prieinamumą.

2. Apžvelgti DARE projektą kaip atvejî, leidžiantị įsigilinti ị aukštojo mokslo prieinamumą socialiai jautrioms grupèms.

3. Nustatyti aukštojo mokslo prieinamumo socialiai jautrioms grupėms veiksnius, leidžiančius atsakyti, kaip ir kodèl šis prieinamumas yra kontekstualizuotas.

Šiame darbe pateikiamo empirinio tyrimo strategija - atvejo studija, kuriai buvo panaudotas šio straipsnio autorių dalyvavimas DARE projekte, skirtame aukštojo mokslo prieinamumo socialiai jautrioms grupèms didinimui ES asocijuotose šalyse Izraelyje ir Gruzijoje, dalyvaujant ES šalių partnerių ekspertams. Tyrimui taikyti šie metodai: mokslinès literatūros analizè, dokumentų analizè, stebejjimas, grupinė diskusija (angl. focus group discussion).

Straipsnio struktūra atitinka tyrimo uždavinius. Pabaigoje pristatomos išvados, atskleidžiančios aukštojo mokslo prieinamumo socialiai jautrioms grupėms kontekstualizavimo esmę ir priežastis.

Esminiai žodžiai: prieinamumas, aukštasis mokslas, socialiai jautrios grupès, žmonès, turintys negalia, moterys, etninès mažumos.

Gauta 20180418 / Received 18042018

Priimta 20180425 / Accepted 25042018 